\title{
Defined Bacterial Populations in the Rumens of Gnotobiotic Lambs
}

\author{
By R. J. LYSONS*, T. J. L. ALEXANDER \\ AND PATRICIA D. WELLSTEAD \\ Department of Clinical Veterinary Medicine, University of Cambridge \\ AND P. N. HOBSON, S. O. MANN AND C. S. STEWART \\ Rowett Research Institute, Bucksburn, Aberdeen
}

(Received I July 1975; revised I8 December 1975)

\begin{abstract}
SUMMARY
Five gnotobiotic lambs were fed on sterile diets until they were killed at 13 to 2 I weeks of age. They were dosed orally with different combinations of I I species of rumen bacteria. The biochemical reactions of each of the bacteria inoculated had been determined in pure culture in vitro, and they were chosen to perform the main reactions known to be associated with digestion in the normal mature rumen.

Two of the bacteria could not be reisolated, but the remainder had established readily in the rumen, forming stable, mixed, defined populations. The total numbers of bacteria in the rumen, and the viable counts of most of the individual species were comparable to those of normal sheep. The concentration of volatile fatty acids was lower, however, and in four of the lambs there was a higher proportion of butyric acid and a lower proportion of propionic acid than in normal sheep. Cellulolytic, ureolytic, and methanogenic activities appeared to be taking place and lactate-utilizing bacteria appeared to reverse the accumulation of lactate which resulted from the activity of lactate-producing bacteria.
\end{abstract}

Some of the bacteria also established at high levels in the caecum.

\section{INTRODUCTION}

The rearing of small omnivurous and carnivorous gnotobiotic animals is a well-established laboratory procedure (Coates, 1968) but ruminants present particular difficulties. Digestion in omnivorous or carnivorous animals can take place without the intervention of gut micro-organisms, but bacteria are essential for digestion in mature ruminants. A young ruminant, fed on milk, might be expected to behave as a monogastric animal and to thrive in the gnotobiotic state while its rumen is still undeveloped, but in the mature ruminant the main digestive action is provided by the micro-organisms of the rumen, regardless of the form of the diet.

The principal reactions of the main components of the rumen microflora, reviewed by Hungate (I966) and Hobson \& Howard (1969), have been established largely from studies of pure cultures in vitro. Information on interactions between rumen bacteria has been obtained from mixed cultures which rarely comprise more than two bacterial species. In such studies 'animal factors are missing and rumen conditions cannot be reproduced. In vivo studies in normal mature ruminants are complicated by the great variety and

* Present address: University of Edinburgh, Veterinary Field Station, Easter Bush, Roslin, Midlothian, Scotland. 
complexity of the rumen microflora. Establishing a relatively simple, stable, fully-defined, functioning population of bacteria in the rumens of gnotobiotic lambs should help to overcome these problems and provide information on the metabolism and interactions of rumen bacteria in vivo which would augment that derived from in vitro studies.

Between 1968 and 1973 a total of 29 gnotobiotic lambs were studied at Cambridge (Alexander \& Lysons, I97I ; Lysons, 1974; Lysons \& Alexander, 1975). This paper reports on five of the lambs which were dosed orally with mixed populations of rumen bacteria. A short communication giving some results has been published (Lysons et al., 197I).

Our main aims were to determine whether all the bacteria inoculated would establish in the rumen, and, if they did so, whether stable populations would persist; whether the total viable counts would be comparable to those found in the rumen of conventional lambs; and whether the bacteria would carry out the biochemical functions for which they were chosen. Attempts were also made to determine whether any of the bacteria established themselves in the caecum.

We thought that a comparatively simple flora should be capable of carrying out the main reactions known to be necessary for digestion (Hungate, 1966; Hobson \& Howard, 1969), and I I bacteria (Table I) were chosen. Under natural conditions the rumen flora develops in stages as the diet of the young animal changes and it was decided, at least in the first experiments, to inoculate the bacteria in the approximate order in which we thought they might develop naturally. The first four bacteria in Table I are major components of the rumen flora of the young animal. Anaerobic bacteria such as those listed in the lower part of Table I become predominant as the animal is weaned. The exception is the facultative anaerobe Streptococcus faecium which frequently occurs in the young animal. It was given last to one lamb in order to perform an additional function.

Although anaerobic ciliate protozoa play a part in rumen reactions their fermentation reactions are similar to those of the bacteria. Protozoa are thought not to be essential to rumen function. As it is impossible to obtain ciliate protozoa reliably free from bacteria, either from the rumen or from culture, a protozoal population was not provided.

\section{METHODS}

Gnotobiotic lambs. The five lambs (Table I) were obtained by hysterectomy and reared in cages inside flexible-film isolators using the equipment and techniques described by Alexander \& Lysons (197I), and Alexander et al. (1973a, b).

Liquid feeds. The lambs were fed on sterile, canned, cows' milk (Carnation Food Co., London WC.2) which was diluted, in the isolator, with I vol. sterile distilled water to 2 vols milk, giving approximately $20 \%$ total solids. Milk feeds were given for periods of between 5 and 10 weeks (Table $\mathrm{I}$ ) and solid feeds were given for varying periods before milk feeding was stopped until the animals were killed for post-mortem examination.

The lambs were given rumen bacteria while they were being fed milk plus solid diet, or solid diet alone (Table I).

Solid feeds. Details of the two solid feeds, which were fed ad libitum, were given by Alexander et al. (1973b). Feed I, a conventional lamb feed, was fed to lambs 9a and Iob. Feed 2, which combined some of the characteristics of a non-ruminant-type feed with those of a ruminant-type feed, was fed to the other three lambs.

Bacteria. The II bacteria listed in Table I were chosen for their biochemical activities, which had been determined in pure culture at the Rowett Research Institute. The strains inoculated had been in laboratory culture for some years, and were well characterized. 
Table I. Sequence and intervals at which rumen bacteria were given orally to gnotobiotic lambs

\begin{tabular}{|c|c|c|c|c|c|c|}
\hline \multirow{5}{*}{$\begin{array}{l}\text { Solid feed first offered } \\
\text { Milk feed stopped } \\
\text { First inoculation }\end{array}$} & \multirow[b]{2}{*}{ Lamb no. ... } & \multicolumn{5}{|c|}{ Age (days) } \\
\hline & & $9 a$ & Iob & $16 a$ & $18 \mathrm{a}$ & $12 b$ \\
\hline & & 39 & 16 & $2 \mathrm{I}$ & $2 \mathrm{I}$ & 44 \\
\hline & & 69 & 37 & 49 & 49 & $5 \mathrm{I}$ \\
\hline & & 68 & 43 & 44 & 44 & 73 \\
\hline & & \multicolumn{5}{|c|}{ Days after first inoculation } \\
\hline & & $9 \mathrm{a}$ & Iob & $16 \mathrm{a}$ & $18 \mathrm{a}$ & $\mathrm{I} 2 \mathrm{~b}$ \\
\hline Streptococcus bovis Strep26 & & 0 & 0 & 0 & $\begin{array}{l}0^{*} \\
2^{*}\end{array}$ & 0 \\
\hline Lactobacillus sp. LB17 & & 0 & 0 & 0 & $\begin{array}{l}0^{*} \\
2^{*}\end{array}$ & NI \\
\hline Veillonella alcalescens $692 / \mathbf{I}$ & & $1^{+}$ & $\mathrm{I}^{\dagger}$ & 0 & $0^{*}$ & 0 \\
\hline & & $2 \dagger$ & $2 \dagger$ & & $2^{*}$ & \\
\hline & & $3^{\dagger}$ & $3 \dagger$ & & & \\
\hline Megasphaera elsdenii $\mathrm{LCI}$ & & $\mathrm{I} \dagger$ & $3 \dagger$ & 0 & $0^{*}$ & 0 \\
\hline & & $2 \dagger$ & $4 \dagger$ & & $2^{*}$ & \\
\hline & & $3 \dagger$ & $5 \dagger$ & & & \\
\hline Butyrivibrio fibrisolvens $\mathrm{B} 834$ & & 15 & 15 & 2 & $0^{*}$ & 2 \\
\hline & & & & & $\mathbf{2}^{*}$ & 7 \\
\hline Bacteroides ruminicola $46 / 5(2)$ & & 22 & 22 & I0 & 13 & 7 \\
\hline & & 23 & 23 & & & \\
\hline & & 24 & 24 & & & \\
\hline & & 28 & 29 & & & \\
\hline & & 29 & 30 & & & \\
\hline Bacteroides amylophilus $\mathrm{HI} 2$ & & 22 & 22 & NI & NI & $\mathrm{NI}$ \\
\hline & & 23 & 25 & & & \\
\hline & & 24 & 26 & & & \\
\hline & & 28 & 28 & & & \\
\hline & & 29 & 29 & & & \\
\hline Ruminococcus sp. 426-3(1) & & 23 & 23 & I0 & 13 & 7 \\
\hline & & .24 & 24 & 29 & & 33 \\
\hline & & 33 & 33 & & & \\
\hline Streptococcus faecium & & NI & NI & NI & NI & 32 \\
\hline Methanobacterium ruminantium MB515I & & NI & NI & NI & NI & 32 \\
\hline Anaerovibrio lipolytica $5 \mathrm{~s}$ & & NI & NI & NI & NI & 33 \\
\hline
\end{tabular}

Day o, first day of inoculation; NI, bacterium not inoculated. All inocula consisted of $10 \mathrm{ml}$ culture medium, except ${ }^{*}$, inoculum consisted of $5 \mathrm{ml}$ rumen contents from lamb $16 \mathrm{a}$; and $\dagger$, inoculum consisted of $100 \mathrm{ml}$ culture medium.

Most were isolated from the rumens of sheep fed on rations containing concentrates; but the lactobacillus and megasphaera were isolated from calves being fed milk, and the strain of Streptococcus bovis was isolated from a red deer feeding on natural pasture. Lactobacillus sp. and Ruminococcus sp. had properties similar to Lactobacillus plantarum and Ruminococcus albus, respectively (Hungate, 1966).

The lactobacillus was inoculated first, to ferment sugars in milk which may have leaked from the oesophageal groove into the undeveloped rumen. Streptococcus bovis, which is a minor but consistent component of the adult rumen flora, was inoculated with the lactobacillus because it was thought that as a facultative anaerobe it would help in reducing the 
rumen fluids to a redox potential, $E_{\mathrm{h}}$, suitable for growth of the strict anaerobes which should later form the principal rumen flora. It was also amylolytic and fermented a number of sugars. Both these bacteria produced lactic acid as a major fermentation product. Lactic acid is undesirable in rumen contents and it is normally fermented to volatile fatty acids. The megasphaera and veillonella were both capable of fulfilling this latter function, producing mainly acetic and propionic acids. The megasphaera also produced some butyric and higher acids and hydrogen and fermented a number of sugars including maltose and sucrose. Megasphaera elsdenii produced considerable quantities of butyric acid when fermenting sugars (Hobson \& Mann, 1961). Butyrivibrio fibrisolvens ferments a wide range of feed carbohydrates, including hemicellulose. The strain used here produced butyrate with acetate, formate and lactate. Bacteroides amylophilus ferments starch, dextrins and maltose to formic, acetic and succinic acids. The strain used was added for its amylolytic properties and also because it was proteolytic. The nitrogen requirements of the different bacteria were varied but would be supplied by this proteolytic activity and the deaminative and proteolytic activities of Bacteroides ruminicola. Deamination would also supply the branched-chain fatty-acid growth factors of the ruminococcus. Bacteroides ruminicola fermented a wide range of feed carbohydrates to lactic, acetic, formic and succinic acids. The formic acid would be expected to accumulate or to be a substrate for methanogenesis, while succinic acid would be decarboxylated to propionic acid by the veillonella. Cellulolytic activity was expected to be provided by the ruminococcus which was very active in vitro on prepared cellulose. Ruminococci can ferment some other carbohydrates including hemicellulose. The strain used here produced acetate, formate and ethanol as its major fermentation products.

It was thought that these eight species, if they established themselves in the rumen, should be capable of degrading feed components to produce the lower volatile fatty acids necessary for the animal's nutritional requirements. In addition to this basic flora, in one of the six gnotobiotic lambs, three further species were added to provide three other normal rumen functions: a strain of Methanobacterium ruminantium which produced methane from formate or hydrogen and carbon dioxide; a strain of Anaerovibrio lipolytica added principally for its lipolytic activity as it was capable of vigorous fermentation of only glycerol and fructose to, mainly, acetic, propionic and succinic acids; and a rumen strain of $S$. faecium which had ureolytic activity (Cook, 1976).

Inoculation. Lambs were dosed orally, at different times, with various amounts of 24 or $48 \mathrm{~h}$ cultures in non-selective broth medium (Table $\mathrm{I}$ ). Lambs $16 \mathrm{a}$ and $18 \mathrm{a}$ were reared at the same time: for convenience, and to find out whether the establishment of bacteria was similar, the first five bacteria were introduced into lamb 18 a by transfer of $5 \mathrm{ml}$ amounts of rumen contents from lamb $16 \mathrm{a}$. No attempt was made to estimate the number of bacteria in any of the inocula.

Sampling of lambs. Details of the methods of sampling have been described by Alexander et al. $(1973 a, b)$.

Samples of rumen contents were withdrawn through a stomach tube into a bottle. They were always taken between 2 and $2 \frac{1}{2} \mathrm{~h}$ after the morning feed, and were removed from the isolator within a few minutes. Caecal contents were studied after removal of the caecum post mortem: examination was started within $30 \mathrm{~min}$ of death. Rumen gas was sampled by inserting a double-ended needle through the left flank of the animal into the dorsal sac of the rumen, and collecting the gas in an evacuated tube. Faeces were removed from the isolator daily.

Bacteriological examination of rumen samples. Except where noted, techniques were based 
on those of Hungate (1950). Serial dilutions were made of rumen liquor in a basal nonselective liquid medium prepared under oxygen-free carbon dioxide. Viable counts of the bacteria were carried out on solid media in roll tubes and plates, or in broth cultures, three sets of roll tubes or liquid cultures being made from each dilution series. In roll tubes, the viable count was taken as the average of the three roll-tube counts at the appropriate dilution. In the broth cultures, the viable count was taken from the highest dilution at which growth was noted in all three tubes.

The non-selective medium used for total viable counts (Medium I of Kurihara et al., I968) contained glucose, maltose, cellobiose and lactate, and supported the growth of all the bacteria except $A$. lipolytica and Meth. ruminantium. The former does not usually ferment any of the sugars in the medium, although our strain showed slow faint growth on cellobiose in pure culture: the latter showed slight growth in the presence of hydrogen produced by the other bacteria. Gram-stained smears were made from 50 randomlyselected colonies and species counts were calculated.

Various other media were used in attempts to separate the bacteria, particularly those which comprised only a small proportion of the total population, so that more accurate counts could be made. The bacteria, and their selective media were: for $S$. bovis, azide agar (Oxoid); for the lactobacillus, Rogosa SL medium (Difco: Rogosa, Mitchell \& Wiseman, 195I); for Veillonella alcalescens and Meg. elsdenii, veillonella agar (Difco: Rogosa et al., 1958). These media were prepared in Petri dishes, inoculated, and incubated under carbon dioxide and hydrogen $(5: 95, \mathrm{v} / \mathrm{v})$. Counts were made by spreading measured drops at serial dilutions over segments of the agar medium. Bacteria were recognized by examining Gram-stained smears from colonies. When colonies of a bacterium were detected but could not be counted accurately because of overgrowth of other bacteria, the count was recorded as being less than a given titre.

Butyrivibrio fibrisolvens occurred in high numbers in rumen samples and was counted on the non-selective medium, as no selective medium was available. The starch-fermenting $B a$. amylophilus and $B a$. ruminocola were counted on a starch medium (Medium 2 of Kurihara et al., I968), but it was difficult or impossible to distinguish between them. The amylolytic $S$. bovis also grew on this medium but could be distinguished by its orange colony. The counts of the cellulolytic ruminococcus were estimated from the highest dilution in which the filter-paper strips in all three tubes of the medium of Mann (I968) were seen to be attacked. Streptococcus faecium was counted on roll tubes of a medium similar to the non-selective one except that it contained mannitol as sole energy source and $6.5 \%(\mathrm{w} / \mathrm{v}) \mathrm{NaCl}$ which inhibited growth of $S$. bovis. Anaerovibrio lipolytica was counted as colonies producing clear zones in roll tubes of a linseed-oil medium (Hobson \& Mann, 196I). Methanobacterium ruminantium was counted in a mineral medium under hydrogen and carbon dioxide (Henderson, 1973). Methanogenesis produces a decrease in gas pressure and dilutions in which this was shown in all three tubes were taken as positive. Gramstained smears were prepared from all rumen samples to check the relative numbers and morphological types of bacteria present.

Bacteriological examination of caecal samples. Caecal bacteria were cultured in a similar manner to the rumen bacteria. In lambs $9 \mathrm{a}, \mathrm{I} 6 \mathrm{a}$ and $\mathrm{i} 8 \mathrm{a}$, the non-selective medium and the cellulose medium were used. In lamb I2b, both of these media were used, as well as the medium for Meth. ruminantium. In lamb Iob, all the non-selective and selective media were used. Gram-stained smears were examined as for rumen samples.

Total counts. These were made initially by a modification of the Breed (I9II) smear technique, using Gram-stained smears. As well as the total number; attempts were made 
to obtain differential counts of the individual species. Total counts were also made with a counting chamber and with a calibrated Coulter Counter (Hobson \& Mann, 1970).

Contaminants. The methods used routinely for monitoring contaminants in the lambs were described by Elliott et al. (1974). In addition, all the rumen and caecal samples considered in this paper were examined for the presence of contaminants.

Biochemical estimations. Volatile fatty acids $\left(\mathrm{C}_{2}\right.$ to $\left.\mathrm{C}_{5}\right)$ were determined by gas-liquid chromatography (Whitelaw et al., 1970). Formic acid was determined by the method of Grant (1947), and lactic acid by the method of Conway (1957). Rumen gas samples were analysed with a mass spectrometer (AEI MSIo). Cellulose digestion was measured as the difference in the lignin:cellulose ratio between diet and faeces. Cellulose was estimated by the method of Barnett (I957). Lignin was estimated by the method of Ellis, Matrone \& Maynard (1946) as modified by Waite, Johnston \& Armstrong (1964). Urease activity in muslin-filtered rumen liquor was determined by the method of Hecker (I971).

\section{RESULTS AND DISCUSSION}

\section{Examination of rumen samples}

Pre-inoculation rumen samples. One or more samples were taken from lambs 9a, Iob, $16 \mathrm{a}$ and $\mathrm{r} 8 \mathrm{a}$ before they were dosed with bacteria. The $\mathrm{pH}$ of the rumen fluid was between 6.5 and $7 \cdot 2$. There was a small concentration of volatile fatty acids (I0 to $15 \mathrm{~mm}$ ) of which about $90 \%$ was acetic acid, presumably from tissue metabolism. Lactic acid was not detected.

Lamb $9 a$. On the day after the first inoculation, S. bovis and the lactobacillus had established viable populations, with $S$. bovis comprising some $90 \%$ of a total count of $9 \times 10^{8} / \mathrm{ml}$ rumen contents (Table 3 ), and the rumen $\mathrm{pH}$ had fallen (Table 2). By the next day the lactobacillus had increased to about $60 \%$ of the population and the $\mathrm{pH}$ had dropped further. On day 3 the lactobacillus count of $8 \times 10^{8} / \mathrm{ml}$ was about $80 \%$ of the total, but the lactate-utilizing $\mathrm{Meg}$. elsdenii was seen in smears, and over the next few days the rumen $\mathrm{pH}$ rose and the lactobacilli decreased in numbers and in proportion of the population ( $20 \%$ on day 5), while $S$. bovis and $\mathrm{Meg}$. elsdenii increased. The total viable counts remained fairly constant at between $9 \times 10^{8}$ and $5 \times 10^{9} / \mathrm{ml}$. In all samples $V$. alcalescens, a very small, Gram-negative coccus, was difficult to distinguish from the Gram-negative background material, but the counts from day ro onwards showed that it established during this first phase of the experiment. Viable counts during the next 7 days (Table 3) showed $S$. bovis to be dominant; and smears indicated that the population was stable over this period. However, a contaminant staphylococcus was noted in films on day 10 and this persisted throughout the experiment. Butyrivibrio fibrisolvens was first observed microscopically 4 days after its inoculation on day I5, but numbers were insufficient for a viable count on day 17 . By day 24 all the bacteria had been inoculated at least once and both viable counts and microscopic observations showed that the flora had become predominantly Gramnegative, as in a sheep reared conventionally. Bacteroides were the principal bacteria detected by viable counts, although it was not possible to distinguish between the two species (Table 3). The total viable count remained at about $4 \times 10^{9} / \mathrm{ml}$, and the proportions of the constituents varied little until the lamb was killed, 38 days after inoculation. Attempts to reisolate the ruminococcus in cellulose medium were unsuccessful.

Total counts increased from $6.4 \times 10^{9} / \mathrm{ml}$ on day 10 to an average of $3.3 \times 10^{10}$ over the last 5 days. At that stage the viable count was about $12 \%$ of the total count which is similar to what might be expected in a normal rumen. 
Table 2. $p H$ and concentrations of fermentation products in rumen samples taken from lambs $9 a$ and $\mathrm{Iob}$

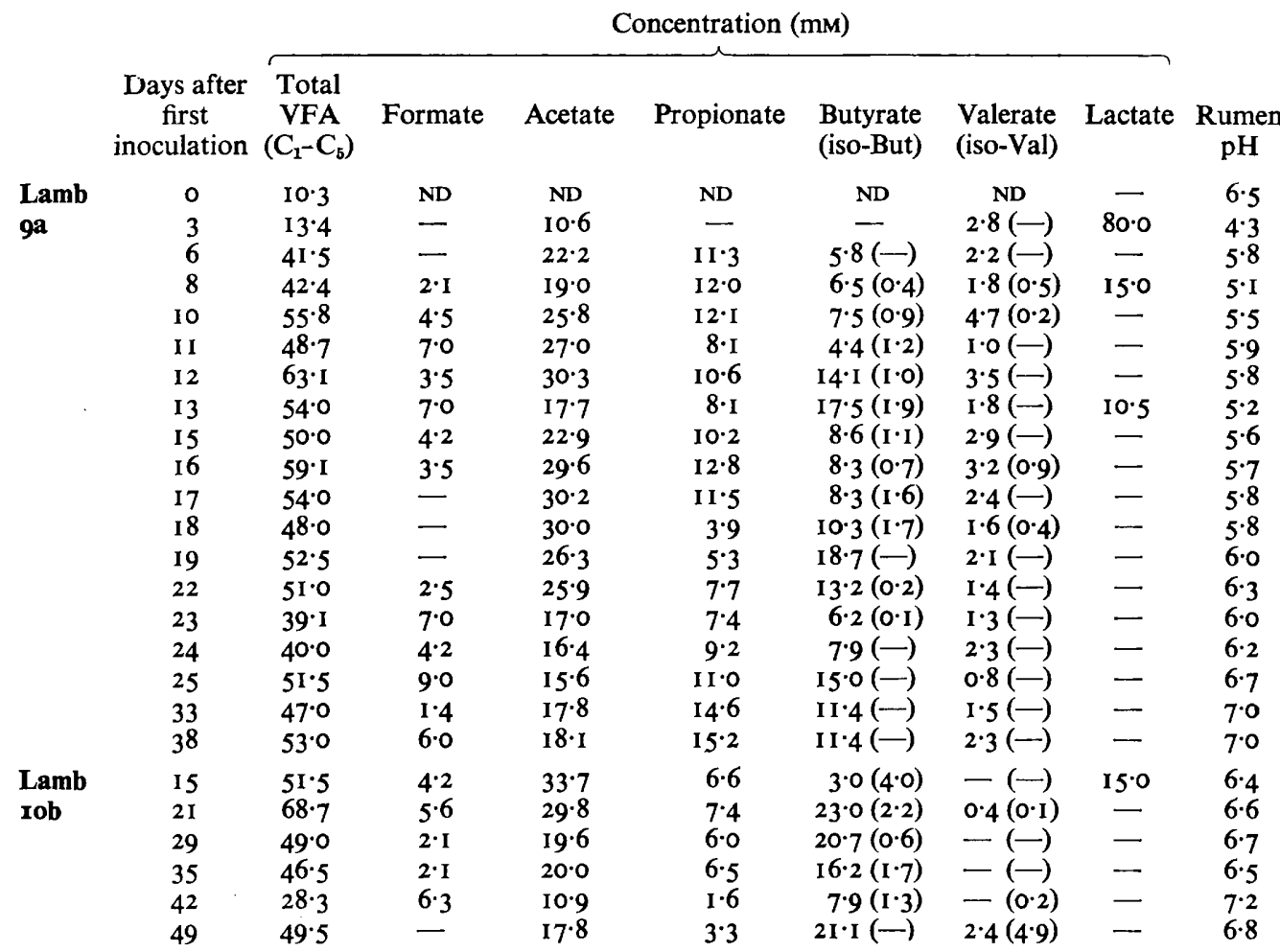

-, Less than $0.1 \mathrm{~mm}$; ND, not determined.

Tests of fermentation products were made more frequently on this lamb than on subsequent lambs. Rumen samples were taken almost daily.

Immediately before inoculation, the rumen $\mathrm{pH}$ was 6.5 and the concentration of volatile fatty acids (VFA) was $10.3 \mathrm{mM}$. On the first 3 days after inoculation the concentration of VFA remained about the same (average $12.4 \mathrm{mM}$ ), but lactic acid concentration was $60 \mathrm{~mm}$ on day $\mathrm{I}$ and $80 \mathrm{~mm}$ on day 3 , and the $\mathrm{pH}$ dropped to $5.5,4.6$ and 4.3 on the three successive days. This coincided with the multiplication of the lactate-producing population dominated first by streptococci, then by lactobacilli. On day 4 the lactic acid concentration had dropped to $40 \mathrm{~mm}$ and the VFA concentration had increased to $22.5 \mathrm{~mm}$, while the $\mathrm{pH}$ had risen to $5^{\circ}$. This trend was followed on subsequent days and paralleled the increase in lactate-utilizing Meg. elsdenii and $V$. alcalescens. The lactate was probably produced mainly by $S$. bovis and Lactobacillus sp., but later also possibly by Ba. ruminicola (Stewart \& Lysons, 1975). On day 6, and subsequently (Table 2), butyric acid could be determined with more confidence. Its rise in concentration occurred before $\mathrm{Bu}$. fibrisolvens was introduced, so it must have come from another source, probably Meg. elsdenii. Megasphaera elsdenii produces more butyrate when it is fermenting sugars than when it is fermenting lactate and in lamb 9a butyrate was generally found in larger amounts when the lactateproducing bacteria were in low numbers. The concentration of butyrate did not increase noticeably after the establishment of $B u$. fibrisolvens, and since this bacterium never became 
Table 3. Numbers of viable bacteria in rumen samples taken from lambs $9 a, 10 b, 16 a, 18 a$ and $12 b$

\begin{tabular}{|c|c|c|c|c|c|c|c|c|}
\hline \multirow[b]{2}{*}{$\begin{array}{c}\text { Days after } \\
\text { first } \\
\text { inoculation }\end{array}$} & \multicolumn{7}{|c|}{$10^{-6} \times$ count $/ \mathrm{ml}$ rumen liquor } & \multirow{2}{*}{$\begin{array}{c}10^{-8} \times \\
\text { total } \\
\text { viable } \\
\text { count } / \mathrm{ml}\end{array}$} \\
\hline & $\begin{array}{l}\text { Strepto- } \\
\text { coccus } \\
\text { bovis }\end{array}$ & $\begin{array}{l}\text { Lacto- } \\
\text { bacillus } \\
\text { sp. }\end{array}$ & $\begin{array}{c}\text { Veillo- } \\
\text { nella } \\
\text { alcalescens }\end{array}$ & $\begin{array}{l}\text { Mega- } \\
\text { sphaera } \\
\text { elsdenii }\end{array}$ & $\begin{array}{c}\text { Butyri- } \\
\text { vibrio } \\
\text { fibrisolvens }\end{array}$ & $\begin{array}{l}\text { Bacteroides } \\
\text { ruminicola }\end{array}$ & $\begin{array}{l}\text { Rumino- } \\
\text { coccus } \\
\text { sp. }\end{array}$ & \\
\hline \multicolumn{9}{|l|}{ Lamb ga } \\
\hline 10 to $17^{*}$ & 2000 & 100 & 40 & $<100$ & NR & & & 30 \\
\hline 24 to $38^{*}$ & 1000 & $<100$ & 1000 & 800 & $<100$ & 2000 & NR & 40 \\
\hline \multicolumn{9}{|l|}{ Lamb rob } \\
\hline 7 & 700 & 200 & IO & 5 & & & & I \\
\hline 15 & 4000 & 100 & 80 & I & & & & 40 \\
\hline $2 \mathrm{I}$ & 1000 & 50 & 200 & 30 & 200 & & & 20 \\
\hline 29 & 400 & 200 & 50 & 0.8 & 200 & NR & $0 . \mathrm{I}$ & 9 \\
\hline 35 & 300 & 80 & 200 & 30 & 40 & 200 & 0.001 & 10 \\
\hline 42 & 800 & 100 & 200 & 20 & $\mathrm{NT}$ & 10 & 0.01 & 60 \\
\hline 49 & 1000 & 20 & 700 & 60 & 200 & 900 & 0.001 & 20 \\
\hline \multicolumn{9}{|l|}{ Lamb r6a } \\
\hline 2 to $10^{*}$ & 2000 & 800 & 200 & 700 & 20000 & & & 100 \\
\hline 93 to $98^{*}$ & 300 & 60 & 900 & 500 & 30000 & 4000 & $0 . I$ & 300 \\
\hline \multicolumn{9}{|l|}{ Lamb r8a } \\
\hline 2 to $13^{*}$ & 7000 & NR & 700 & $<\mathrm{I}$ & I 000 & & & 90 \\
\hline 61 to $70^{*}$ & 300 & 30 & 700 & 700 & 20000 & 2000 & 0.001 & 200 \\
\hline \multicolumn{9}{|l|}{ Lamb 12b } \\
\hline 19 to $27^{*}$ & 600 & & 200 & 10 & 200 & 8 & NR & 7 \\
\hline 55 to $64^{*} \dagger$ & 700 & & 200 & 2 & 900 & 200 & 0.001 & 20 \\
\hline
\end{tabular}

Blank spaces occur where bacteria had not then been inoculated (see Table 1).

NR, Bacteria not reisolated; NT, not tested.

* Single counts or average of a number of counts made during the period.

† In lamb I 2a, viable counts/ml rumen liquor of the extra bacteria in the period 55-64 days after first inoculation were: Streptococcus faecium, $1 \times \mathrm{IO}^{7} ;$ Methanobacterium ruminatium, $1 \mathrm{O}^{4}$. Anaerovibrio lipolytica was not reisolated. On day 75, the viable count of Ruminococcus sp. was $10^{4} / \mathrm{ml}$ and Meth. ruminantium was $10^{6} \mathrm{ml}$.

a major fraction of the population, most butyric acid production may have been due to Meg. elsdenii. The small amounts of valeric acid detected from day 3 onwards could also have been formed by this bacterium, since it is the only one present known to form valeric acid by fermentation (Hobson \& Mann, 1961).

Propionate can be produced directly by $\mathrm{Meg}$. elsdenii and $\mathrm{Bu}$. fibrisolvens, and indirectly by $V$. alcalescens which decarboxylates succinate produced by bacteroides or ruminococcus. Acetate is a fermentation product of all the bacteria. Formate can also be formed by all the species and its accumulation in the rumen, in levels higher than normally found in conventionally-reared lambs, would be expected in the absence of methanogenic bacteria.

Once the complete flora was established the rumen $\mathrm{pH}$ remained relatively constant.

Lamb rob. This lamb was inoculated with the same eight bacteria as lamb 9a (Table 1 ), but the first bacteria were not introduced until after milk feeding had stopped, because it was thought that the fermentation of residual milk sugars had contributed towards the initial drop in rumen $\mathrm{pH}$ in lamb 9a. Lamb $\mathrm{Iob}$ was also inoculated when younger and was kept alive longer after inoculation to allow more time for studying the flora and for the ruminococcus to establish itself.

Two to three days after the first inoculation, Lactobacillus sp. had not reached as 
high a proportion of the population (Table 3) as in lamb 9a, and the rumen $\mathrm{pH}$ (Table 2) did not fall rapidly even though the delay in giving $M e g$. elsdenii meant that $V$. alcalescens was the only lactate-utilizing bacterium present until day 3. By day 15 (Table 3 ) the four bacteria inoculated had established in a pattern similar to that in lamb $9 \mathrm{a}$. By day 29 ( 6 days after its inoculation) a small population of ruminococci could be detected in viable counts, but this did not increase even after a third inoculation on day 33. The number of viable ruminococci present may have been higher than estimated because this bacterium normally colonizes cellulosic fibres, which were not readily collected by the narrow-bored stomach tube, and from which it is not readily dislodged. It is also a difficult bacterium to detect visually in Gram-stained films.

The composition of the population remained relatively stable until the lamb was killed on day 5I. Microscopic examinations suggested that Bu. fibrisolvens formed a larger proportion of the population than indicated by the viable counts, suggesting a high proportion of non-viable cells. Bacteroides ruminicola was identified in stained smears, but Ba. amylophilus was not identified either by direct observation or by culture. A contaminant streptococcus was detected on day 35 and remained part of the population.

Before inoculation, the rumen $\mathrm{pH}$ value was $7 \cdot 2$. On the day after inoculation, the rumen $\mathrm{pH}$ had fallen to 5.2 and the concentration of lactic acid was $40.0 \mathrm{~mm}$. By the next day the $\mathrm{pH}$ was 6.3 and lactic acid was not determinable, and it remained so except on day $\mathrm{I} 5$. By day 7 the rumen $\mathrm{pH}$ was $6 \cdot 6$. Total volatile fatty acids increased after day $\mathrm{I}$, from their pre-inoculation concentration of $9 \cdot \mathrm{I} \mathrm{mM}$ to $26 \cdot 3 \mathrm{mM}$ on day 7 . The rest of the analyses are shown in Table 2.

As with lamb 9a, acetic acid concentration decreased as the flora became more complex. The proportion of propionate in the acids was less in this lamb than in lamb 9a, possibly reflecting a smaller proportion of bacteroides and megasphaera. However, higher butyrate concentrations were evident in most samples taken after the introduction of $\mathrm{Bu}$. fibrisolvens.

Lamb I6a. Inoculation began six days before milk feeding stopped, but the lactateutilizing bacteria were added with the lactate producers to prevent the increase in lactic acid and drop in $\mathrm{pH}$ noted in lamb 9a. Bacteria were introduced over a shorter period than in the two previous lambs (Table I). Bacteroides amylophilus was not given to this and the two subsequent lambs, because it had proved difficult to identify and its amylolytic and proteolytic properties should have been covered by the other bacteria.

Streptococcus bovis dominated on day I. The lactobacilli were dominant on day 2, but decreased in number on day 3. Butyribivrio fibrisolvens then became dominant both in stained preparations and on viable counts: it remained so until the end of the experiment (Table 3). After the introduction of the remaining two bacteria (Table I) the flora remained stable, the viable counts being similar to those recorded between days 93 and 98 (Table 3). Total viable counts were in excess of $10^{10}$ bacteria/ml rumen liquor, i.e. comparable with the highest counts recorded in sheep reared conventionally. The lamb was killed on day 98 . A contaminant clostridium was detected at about day 50.

On the day of inoculation, the rumen VFA concentration was $12.9 \mathrm{~mm}$ and the $\mathrm{pH} 6.8$. The $\mathrm{pH}$ dropped to 5.0 on day I when the lactate concentration was $29.0 \mathrm{~mm}$, but had recovered to 6.0 by days 2 and 3 when the lactate concentration had diminished to 3.0 and $5.4 \mathrm{mM}$. On day 2 , the VFA concentration was $46.5 \mathrm{~mm}$ and on day $3,54.9 \mathrm{~mm}$. Results selected to demonstrate the main trends (Table 4) show that the butyrate concentration was high and the propionate low from days 7 to I0, reflecting the high population of butyrivibrio. Although propionate remained low, there was a rise after the introduction of the succinate-producing bacteroides on day 10. 
Table 4. $p H$ and concentration of fermentation products in rumen samples taken from lambs I $6 a, \mathrm{I} 8 a$ and $\mathrm{I} 2 b$

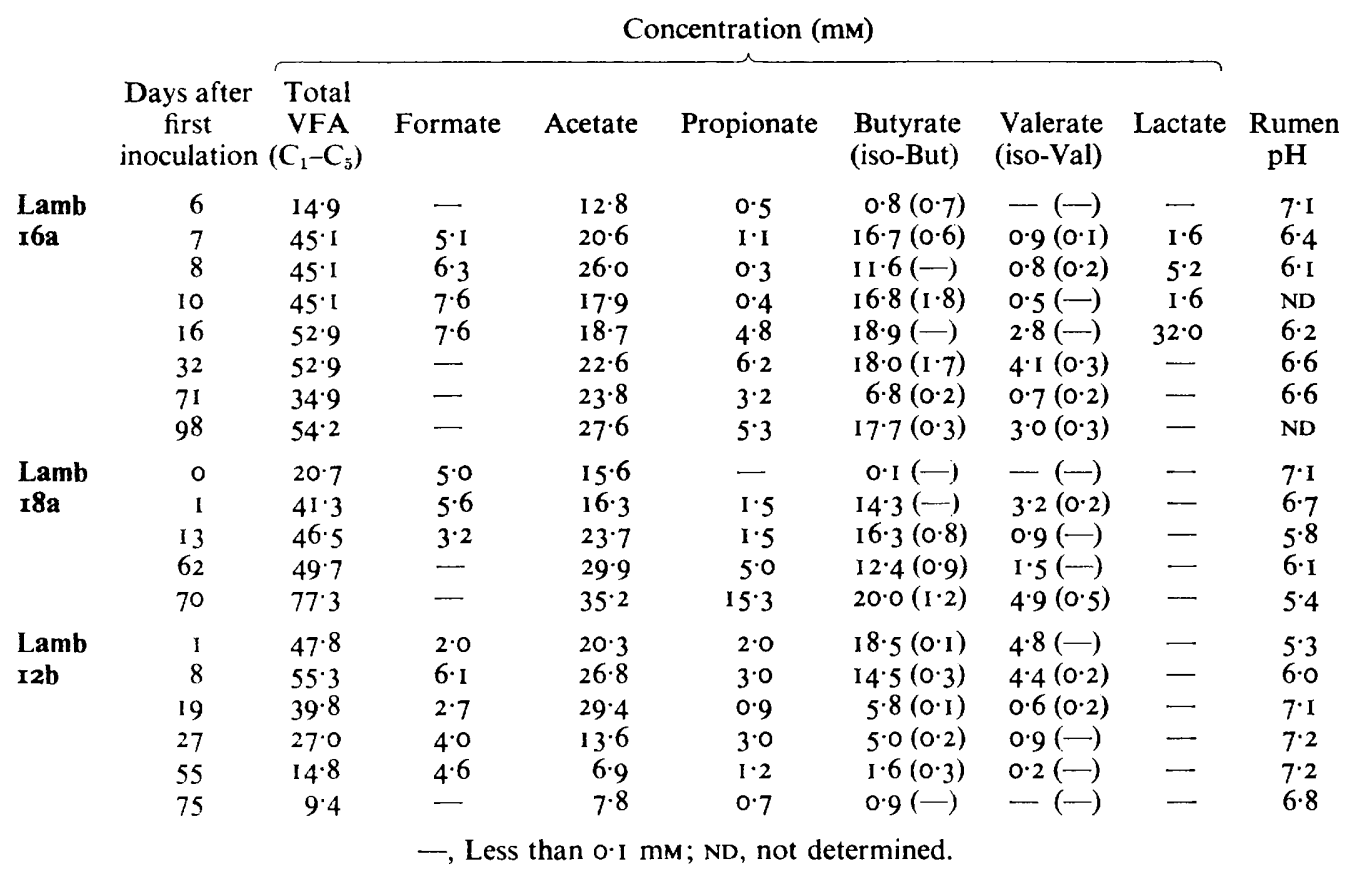

A comparison of dietary and faecal cellulose:lignin ratios indicated that about $20 \%$ of the cellulose present in the ration had been digested by this lamb.

$L a m b$ I $8 a$. The feeding regime and times of inoculation were the same as for lamb i6a, but the first bacteria were introduced by inoculation of rumen contents from lamb i6a. They were collected 6 and 8 days after lamb i6a had first been inoculated. One day after inoculation, $S$. bovis was dominant, with Lactobacillus sp. and Meg. elsdenii also present. This contrasted with the population in the inoculum. At this time, Bu. fibrisolvens was dominant in lamb I6a. However, cultural counts on days 2 to 13 (Table 3) showed that $B u$. fibrisolvens rapidly became a major part of the flora and, eventually, the dominant bacterium in lamb $18 \mathrm{a}$. As with lamb $16 \mathrm{a}$, total viable counts in rumen liquor were high.

A number of contaminants, including clostridia (Elliott et al., 1974; Lysons, 1974), developed in the rumen, and between days 65 and 69 were detectable in numbers up to about $10^{i} / \mathrm{ml}$. The experiment was terminated on day 70 .

Rumen analysis before inoculation was similar to those of the other lambs. Lactate was not detected (Table 4), but the lactobacilli became only a minor part of the population. The concentration of butyrate on day I was similar to that in lamb I6a and suggests that although $\mathrm{Bu}$. fibrisolvens was not detected in Gram-stained films of rumen contents until day 2 it may have been active from the start. The preponderance of butyric acid in all the samples was similar to that in lamb $16 \mathrm{a}$ and reflected the continuing high numbers of $B u$. fibrisolvens. The lamb was shown to have digested about $15 \%$ of dietary cellulose.

Lamb I $2 b$. Milk feeding was stopped when this lamb was 5I days old, but the bacteria were not given until 22 days later. Lactobacillus sp. (Table I) was omitted as the inocula were given well after milk feeding had stopped. This lamb was the one given the ureolytic, methanogenic and lipolytic bacteria (Table 3). 
Streptococcus bovis established itself quickly and was dominant on day I; Meg. elsdenii had increased in numbers on day 2. The flora remained stable with the streptococcus dominant until after the other bacteria were introduced on day 7 (Table I). On day 8, $B u$. fibrisolvens appeared to be the dominant bacterium, with $S$. bovis, Meg. elsdenii and $B a$. ruminocola also present in high numbers. Microscopic observations suggested that $B u$. fibrisolvens formed a larger proportion of the population than indicated by the cultural counts (Table 3). Ruminococcus sp. could not be detected after 27 days so a second inoculum was given on day 33 , and a small population was subsequently detected. Of the three additional bacterial species (Table 3), two had established themselves by day 55 . Anaerovibrio lipolytica was not reisolated in culture nor detected in smears. The lamb was killed on day 76 .

Lactic acid was not found in the rumen of this lamb (Table 4) reflecting the absence of lactobacilli. Presumably the activity of Meg. elsdenii and $V$. alcalescens was sufficient to metabolize all the lactic acid produced by the streptococcus and bacteroides. The butyrate concentration remained high and the propionate concentration low until between days 19 and 27 , reflecting the dominant flora. There was a decrease in the total VFA concentration on days 27,55 and 75 (Table 4) which probably resulted from this lamb's poor appetite. It ate little in the last weeks of life and lost some weight (Lysons, 1974; Lysons \& Alexander, 1975). The lamb was shown to have digested about $22 \%$ of dietary cellulose.

Ureolytic activity was not detected in rumen liquor before the introduction of $S$. faecium. After it had been introduced $5 \mathrm{ml}$ samples of rumen liquor released 9 to $24 \mu \mathrm{g}$ of ammonia from added urea over a Io min period.

Other analyses. Rumen gas samples were taken from several lambs, both before and after inoculation. Unfortunately, the methods of collection led to contamination with air. Carbon dioxide was always in excess of that in normal air both before and after inoculation and in some of the samples hydrogen was similarly in excess, particularly after inoculation.

Methane was measured from the height of the $m / e$ is peak, which had previously been shown to be proportional to the methane content of a gas mixture. However, as air constituted a large proportion of many samples the partial pressure of methane was very low and so the ratio of the heights of the $m / e$ I 5 to $m / e 44\left(\mathrm{CO}_{2}\right)$ peaks was taken as a measure of the methane content of the gas. Thirteen gas samples were taken from lamb $\mathrm{I} 2 \mathrm{~b}$ in the period from 2 days before inoculation with bacteria until the end of the experiment. Up to, and including day 38 , the height of the $m / e$ I 5 peak was similar to that in the background spectrum, as it was in samples from other lambs. The next sample, on day 53, and subsequent samples, to day 65 , showed a Io-fold increase in the ratio of $\mathrm{m} / \mathrm{e}$ I5 to $\mathrm{m} / \mathrm{e} 44$ peaks. Two samples taken at about this time from the air inside the isolator also showed $m / e$ I 5 peaks that were higher than the background. These results were taken, along with the cultural results, to indicate an active methanogenic flora.

It was not possible to study bacterial amylase, lipase and protease activity in the rumen since these enzymes were present at variable levels in the feed and in pre-inoculation rumen samples.

\section{Examination of caecal samples}

Total viable counts ranged from $6 \times 10^{8}$ to $\mathrm{I} \times 1 \mathrm{I}^{10} / \mathrm{ml}$ caecal contents. In lambs 9 a and I2b, Gram-positive cocci (presumably $S$. bovis and, possibly in I2b, $S$. faecium) were dominant in Gram-stained films. Smaller numbers of Meg. elsdenii and lactobacilli in lamb 9a and $\mathrm{Ba}$. ruminicola in lamb $\mathrm{I} 2 \mathrm{~b}$ were also noted. Methanobacterium ruminantium was not detected.

The caecal flora of lamb Iob was studied in most detail. The total viable count was 
$5 \times 10^{9} / \mathrm{ml}$, with $S$. bovis dominant. The counts for other bacteria were lower: $V$. alcalescens and $\mathrm{Ba}$. ruminicola, $2 \times \mathrm{IO}^{8} / \mathrm{ml}$; Lactobacillus sp., $4 \times \mathrm{IO}^{7} / \mathrm{ml}$; and Meg. elsdenii, $<\mathrm{IO}^{6} / \mathrm{ml}$. The contaminant streptococcus previously noted in the rumen was also present.

In lamb ı $6 \mathrm{a}, S$. bovis and $B a$. ruminicola were again dominant in viable counts, with Meg. elsdenii $\left(2 \times 10^{9} / \mathrm{ml}\right)$ present in similar numbers. The clostridium was also present in high numbers.

In lamb i $8 \mathrm{a}$, the picture was much the same, and again the clostridial contaminant was present in high numbers (about $10^{9} / \mathrm{ml}$ ). A species of Neisseria was also a contaminant at $5 \times 10^{8} / \mathrm{ml}$.

Neither Bu. fibrisolvens nor Ruminococcus sp. could be identified in any of the samples.

\section{CONCLUSIONS}

It has been reported (Lysons, 1975) that a single species of rumen bacteria, Ba. ruminicola, can establish itself in a gnotobiotic lamb. We have now shown that mixed defined bacterial populations can also be established in vivo. The functions of these defined floras are largely predictable from the reactions, in vitro, of their constituents. The most striking example was the development of the initial populations, where the addition of lactate-utilizing bacteria appeared to reverse the accumulation of lactate due to the activity of lactateproducing bacteria. When all the bacteria had been introduced, the rumen flora of the lambs became preponderantly Gram-negative, as in conventionally-reared lambs. The final flora exhibited a stability similar to that of the normal rumen. The general preponderance of $\mathrm{Bu}$. fibrisolvens could be explained by its wide range of fermentative abilities. Ruminococcus sp. did not seem to grow in large numbers and this could be due to a limited ability to attack cellulose in the plant structure. The results indicated, however, that cellulolysis had taken place. It is also possible that some of the strains of bacteria had changed in the course of many passages in laboratory media which may have affected their ability to establish themselves and grow in the rumen.

The concentration of VFA in the rumen was less than that usually reported for sheep, although the total numbers of bacteria and the viable counts of most of the individual species were comparable to the highest recorded for sheep reared conventionally.

The mixture of VFA generally contained a higher proportion of butyric acid and lower proportion of propionic acid than is normally found. Only in lamb ga, where the butyrivibrio did not form a large proportion of the population, was the propionic acid concentration higher than butyrate and nearer the normal values. This would suggest that to obtain a more normal rumen VFA mixture the population should include other species of bacteria producing propionate or succinate which could establish themselves in high numbers. However, a detailed assessment of activity of the rumen bacteria is complicated by absorption of fermentation products through the walls of the rumen. This absorption depends on rumen development and the degree of development may have varied in different lambs (Lysons \& Alexander, 1975; Lysons et al., 1976).

Gnotobiotic lambs can, therefore, be used to provide a model for investigating the actions and interactions of selected mixtures of rumen bacteria in vivo.

We wish to acknowledge the skilled assistance of Miss L. M. Elliott and the help and encouragement of Professor A. T. Phillipson. The work was supported by grants from the Wellcome Trust and the Agricultural Research Council. 


\section{REFERENCES}

Alexander, T. J. L. \& Lysons, R. J. (1971). Observations on rearing gnotobiotic lambs. British Veterinary Journal 127, 349-357.

Alexander, T. J. L., Lysons, R. J., Elliott, L. M. \& Wellstead, P. D. (I973a). Equipment for rearing gnotobiotic lambs. Laboratory Animals 7, 195-2 I7.

Alexander, T. J. L., Lysons, R. J., Elliott, L. M. \& Wellstead, P. D. (1973b). Techniques for rearing gnotobiotic lambs. Laboratory Animals 7, 239-254.

BARNETT, A. J. G. (I957). Studies on the digestibility of the cellulose fraction of grassland products. I. The relation between the digestibility of silage cellulose as determined in vitro and silage crude fibre digestibility determined by feeding trial. Journal of Agricultural Science, Cambridge 49, 467-474.

BREED, R. S. (I9I I). The determination of the number of bacteria in milk by direct microscopical examination. Zentralblatt für Bakteriologie, Parasitenkunde, Infectionskrankheiten und Hygiene (Abteilung II) 30, 337-340.

CoATES, M. E. (1968). Editor. The Germfree Animal in Research. New York and London: Academic.

Conway, E. J. (1957). Microdiffusion Analysis and Volumetric Error, 4th edn. London: Crosby Lockwood.

Cook, A. R. (1976). Urease activity in the rumen of sheep and the isolation of ureolytic bacteria. Journal of General Microbiology 92, 32-48.

Elliott, L. M., AleXander, T. J. L., Wellstead, P. D. \& Lysons, R. J. ( I974). Microbiological monitoring of gnotobiotic lambs. Laboratory Animals 8, $5 \mathrm{I}-59$.

Ellis, G. H., Matrone, G. \& Maynard, L. A. (1946). A 72 per cent $\mathrm{H}_{2} \mathrm{SO}_{4}$ method for the determination of lignin and its use in animal nutritional studies. Journal of Animal Science 5, 285-297.

Grant, W. M. (1947). Colorimeter micromethod for determination of formic acid. Industrial and Engineering Chemistry, Analytical Edition 19, 206-207.

HeCKER, J. (197I). Metabolism of nitrogenous compounds in the large intestine of sheep. British Journal of Nutrition 25, 85-95.

Henderson, C. (1973). The effects of fatty acids on pure cultures of rumen bacteria. Journal of Agricultural Science, Cambridge 81, I07-1 12.

Hobson, P. N. \& HowaRd, B. H. (1969). Microbial transformations. In Handbuch der Tierernahrung, vol. I, pp. 207-254. Edited by W. Lenkeit, K. Breirem and E. Craseman. Hamburg and Berlin: Paul Parey.

Hobson, P. N. \& ManN, S. O. (I96I). The isolation of glycerol-fermenting and lipolytic bacteria from the rumen of the sheep. Journal of General Microbiology 25, 227-240.

Hobson, P. N. \& ManN, S. O. (1970). Applications of the Coulter Counter in microbiology. In Automation, Mechanization and Data Handling in Microbiology, pp. 9I-105. Edited by A. Baillie and R. J. Gilbert. London and New York: Academic.

Hungate, R. E. (1950). The anaerobic mesophilic cellulolytic bacteria. Bacterial Reviews 14, I-49.

Hungate, R. E. (I 966). The Rumen and its Microbes. New York and London: Academic.

Kurihara, Y., Eadie, J. M., Hobson, P. N. \& ManN, S. O. (I968). Relationship between bacteria and ciliate protozoa in the sheep rumen. Journal of General Microbiology 51, 267-288.

Lysons, R. J. (1974). Studies of lambs with a limited microflora. Ph.D. thesis, University of Cambridge.

Lysons, R. J. (1975). The establishment of Bacteroides ruminicola in a gnotobiotic lamb. Journal of General Microbiology 87, 170-172.

Lysons, R. J. \& AleXANDer, T. J. L. (1975). The gnotobiotic ruminant and in vivo studies of defined bacterial populations. In Digestion and Metabolism in the Ruminant, pp. 180-192. Edited by I. W. McDonald. University of New England.

Lysons, R. J., Alexander, T. J. L., Hobson, P. N., Mann, S. O. \& Stewart, C. S. (1971). Establishment of a limited rumen microflora in gnotobiotic lambs. Research in Veterinary Science, 2, 486-487.

Lysons, R. J., Alexander, T. J. L., Wellstead, P. D. \& Jennings, I. W. (1976). Observations on the alimentary tract of gnotobiotic lambs. Research in Veterinary Science 20, 70-76.

ManN, S. O. (1968). An improved method of determining cellulolytic activity in anaerobic bacteria. Journal of Applied Bacteriology 3I, 24I-244.

Rogosa, M., Fitzgerald, R. J., Mackintosh, M. E. \& Beaman, A. J. (I958). Improved medium for selective isolation of Veillonella. Journal of Bacteriology 76, 455-456.

Rogosa, M., Mitchell, J. A. \& Wiseman, R. F. (195I). A selective medium for the isolation and enumeration of oral and faecal lactobacilli. Journal of Bacteriology 62, 132-1 33.

StewART, C. S. \& LySONS, R. J. (I975). Fermentation products in the rumen of a gnotobiotic lamb dosed with Bacteroides ruminicola. Proceedings of the Nutrition Society 34, 72A-73A.

WaIte, R., Johnston, M. J. \& ARmstrong, D. G. (1964). The evaluation of artificially dried grass as a source of energy for sheep. I. The effect of stage of maturity on the apparent digestibility of rye-grass, cocksfoot and timothy. Journal of Agricultural Science, Cambridge 62, 391-398.

Whitelaw, F. G., HyldgaARD-Jensen, J., Reid, R. S. \& KAY, M. G. (1970). Volatile fatty acid production in the rumen of cattle given an all concentrate diet. British Journal of Nutrition 24, I79-195. 